\title{
32. GEOCHEMISTRY OF CARBON: DSDP LEG 31
}

\author{
J. G. Erdman, K. S. Schorno, and R. S. Scalan, Phillips Petroleum Company, \\ Bartlesville, Oklahoma
}

\section{INTRODUCTION}

Eleven core sections from Sites 299 and 302, on DSDP Leg 31 in the Sea of Japan (Figure 1), were received through the JOIDES Organic Geochemistry Subcommittee. Collected for geochemical study, these core sections had been frozen on shipboard in their plastic liners and remained frozen thereafter.

\section{PROCEDURES}

A channel was cut down each side of the plastic liner using a milling machine, an aspirator removing chips of plastic. All parts of the milling machine which could come in contact with the sample were freed of oil using methylene chloride. The final cut through the liner was made with a sharp knife. The core section then was supported in a jig, allowed to thaw, and split using a piece of steel wire. The half sections were refrozen.

The flat surfaces of the core sections were smoothed for description and photographing, using the milling machine fitted with a flycutter. Photographs, diagrams of textural or color patterns, and brief lithological descriptions are contained in the overlays on Figures 2-12.

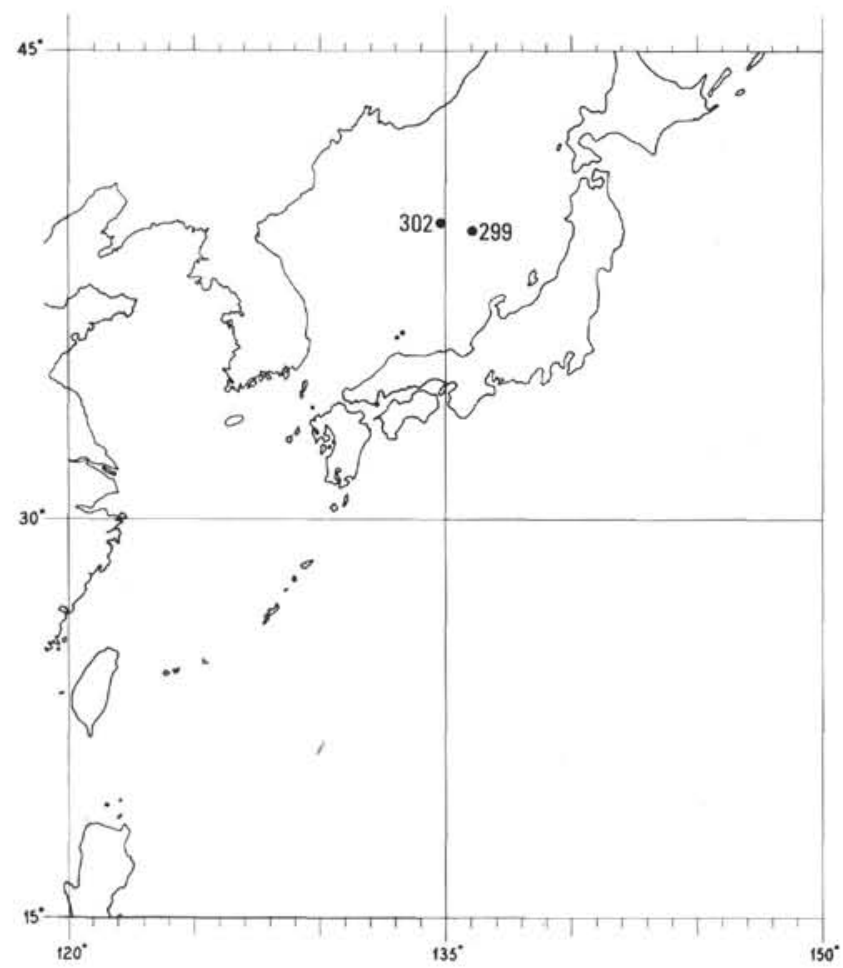

Figure 1. Location of sites from which samples for geochemical study were obtained.
Chip samples, 5-10 mg in size, of each textural type or color were removed for determination of carbonate carbon and organic carbon, the values for which are noted in Table 1. The vertical orientation of the cores, i. e., which end is top, unfortunately was not recorded on shipboard. The remaining determinations described in this report were made on linear strips of the sample. The procedure for separation and determination of carbon species has been described previously (Erdman et al., 1974 , in press).

\section{RESULTS AND DISCUSSION}

Tables 2 and 3 list the data representative of the bulk samples, i.e., the average for the entire core sections. Although in relatively close proximity, correlation between sediment intervals is not as striking as with the samples from Holes 280A, 281, and 282 on DSDP Leg 29, west and south of Tasmania (Erdman et al., in press). For this reason, the data are ordered in respect to

TABLE 1

Carbonate and Organic Carbon Values for Inclusions Noted in Figures 2-11

\begin{tabular}{|c|c|c|c|c|}
\hline \multirow[b]{2}{*}{ Figure } & \multirow[b]{2}{*}{ Inclusion } & \multicolumn{2}{|c|}{ Carbonates } & \multirow{2}{*}{$\begin{array}{l}\text { Organic } \\
\text { Carbon } \\
\text { (wt. \%) }\end{array}$} \\
\hline & & $\begin{array}{l}\text { Carbon } \\
\text { (wt. \%) }\end{array}$ & $\begin{array}{l}\text { Calcium } \\
\text { (wt. \%) }\end{array}$ & \\
\hline 2 & 1 & 0.09 & 0.75 & 0.05 \\
\hline \multirow[t]{4}{*}{3} & 1 & 0.24 & 2.00 & 2.22 \\
\hline & 2 & 0.04 & 0.33 & 0.90 \\
\hline & 3 & & & 1.46 \\
\hline & 4 & & & 1.00 \\
\hline \multirow[t]{3}{*}{4} & 1 & 0.05 & 0.42 & 0.64 \\
\hline & 2 & 0.03 & 0.25 & 0.45 \\
\hline & 3 & 0.11 & 0.92 & 0.54 \\
\hline \multirow[t]{3}{*}{5} & 1 & 0.08 & 0.67 & 0.41 \\
\hline & 2 & 0.09 & 0.75 & 0.29 \\
\hline & 3 & 0.46 & 3.83 & 0.55 \\
\hline \multirow[t]{4}{*}{6} & 1 & 0.87 & 7.25 & 4.26 \\
\hline & 2 & 0.10 & 0.83 & 0.57 \\
\hline & 3 & 1.32 & 11.00 & 0.35 \\
\hline & 4 & 0.17 & 1.41 & 0.35 \\
\hline \multirow[t]{3}{*}{7} & 1 & 0.73 & 6.08 & 2.79 \\
\hline & 2 & 1.17 & 9.75 & 0.49 \\
\hline & 3 & 0.11 & 0.92 & 0.56 \\
\hline \multirow[t]{2}{*}{8} & 1 & 0.50 & 4.17 & 0.71 \\
\hline & 2 & 0.07 & 0.58 & 0.79 \\
\hline \multirow[t]{3}{*}{9} & 1 & 0.05 & 0.42 & 0.57 \\
\hline & 2 & 0.09 & 0.75 & 0.61 \\
\hline & 3 & 0.01 & 0.08 & 0.56 \\
\hline \multirow[t]{2}{*}{10} & 1 & 0.04 & 0.33 & 0.65 \\
\hline & 2 & 0.11 & 0.92 & 0.71 \\
\hline \multirow[t]{2}{*}{11} & 1 & 0.03 & 0.25 & 0.57 \\
\hline & 2 & 0.03 & 0.25 & 0.65 \\
\hline \multirow[t]{2}{*}{12} & 1 & 0.07 & 0.58 & 0.79 \\
\hline & 2 & 0.07 & 0.58 & 0.79 \\
\hline
\end{tabular}




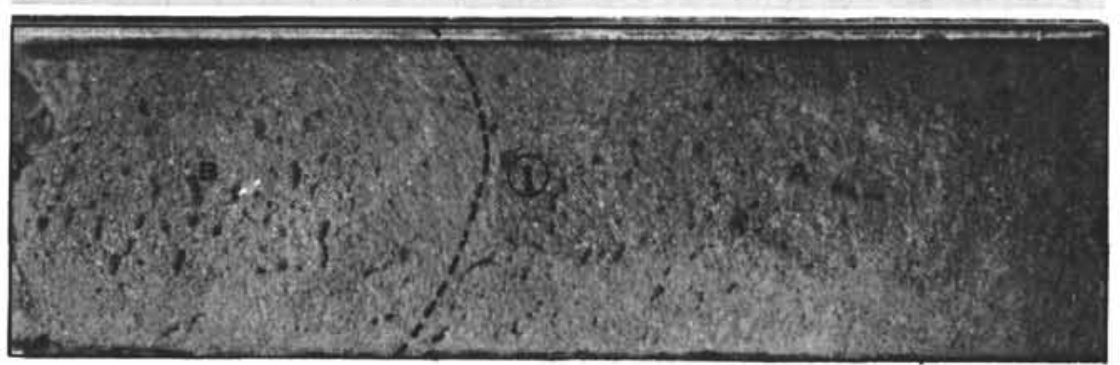

Figure 2. Site 299, Core 17, Section 3. Unit A - medium-dark-gray (N4), soft, plastic firm, very poorly sorted, immature, clayey, silty, fine-to mediumgrained quartzose sandstone. Unit $A$ is moderately calcareous and contains common calcareous foraminifera and calcareous nannoplankton. Sample contains $2 \%-3 \%$ biotite mica; $3 \%$ black amphibole or pyroxene; $5 \%$ orthoquartzite rock fragments; $3 \%$ dark-reddish-orange unidentified mineral fragments; $40 \%$ fine- to medium-grained, poorly sorted, very angular quartzose sand; $27 \%$ quartzose silt; and $20 \%$ claysize fraction. This sample possibly represents turbidite deposition. Unit $B$ - same as above, but containing a greater proportion of clay-size fraction. Consists of about $40 \%$ clay-size, $30 \%$ silt-size, and $30 \%$ very fine- to medium-grained quartzose sand fraction.

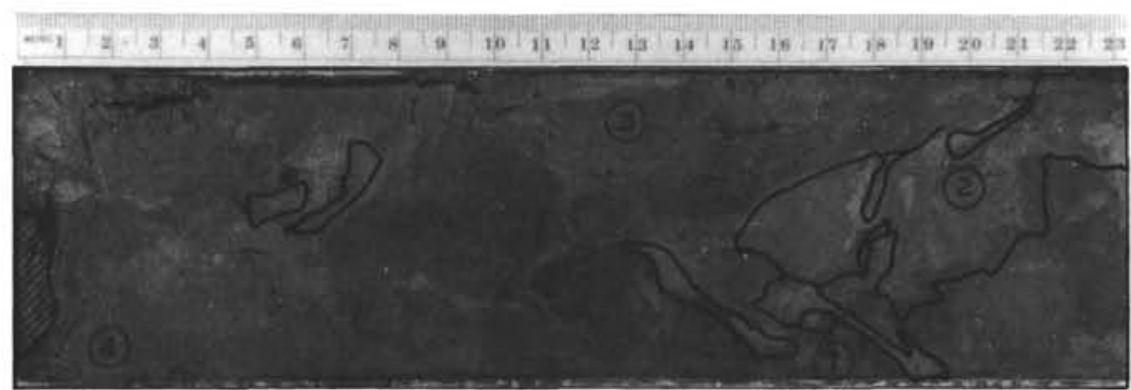

Figure 3. Site 299, Core 22, Section 1. Varicolored, soft, plastic, firm, nonbedded, bioturbated or flow disturbed, noncalcareous, diatom- and silicoflagellate-rich, mostly olive-gray (5Y $3 / 2)$, grayish-olive $(10 Y 4 / 2)$ and grayish-green (5G 5/2) clay. Lithology appears to be uniform throughout, although the olive-gray units are a less pure fossiliferous clay, somewhat glauconitic, and containing up to $20 \%$ fine quartzose silt. No calcareous nannoplankton or foraminifera were noted. Fossils are all of the siliceous type: diatoms, sponge spicules, silicoflagellates.

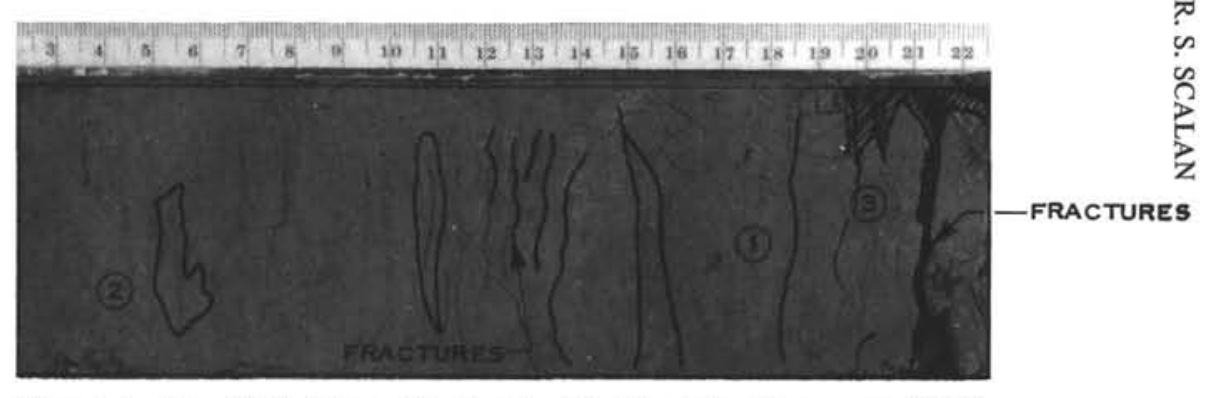

Figure 4. Site 299, Core 30, Section 3. Grayish-olive-green (5GY $3 / 2$ ), soft, firm, massive, nonbedded, horizontally fractured, very fossiliferous clay. Sample appears to be firm and somewhat indurated within the upper $40 \mathrm{~mm}$. Sample consists of abundant siliceous remains of diatoms, sponge spicules, silicoflagellates, and rare radiolarians, comprising about $40 \%$ of the sample. Remainder of sample is clay-size fraction devoid of calcareous organisms. Sample contains several olive-gray ( $5 Y 3 / 2)$ and light-olive-gray $(5 Y 5 / 2)$ discontinuous lenses and seams of sediment identical in lithology to the dominant olive-green core. These lenses appear to be due to horizontal plastic flow. The lower $25-30 \mathrm{~mm}$ of this sample is distinctly quartzose silty, containing several $1-3 \mathrm{~mm}$ diameter circular to ovate patches of clean, well sorted, very angular, fine quartzose silt. 


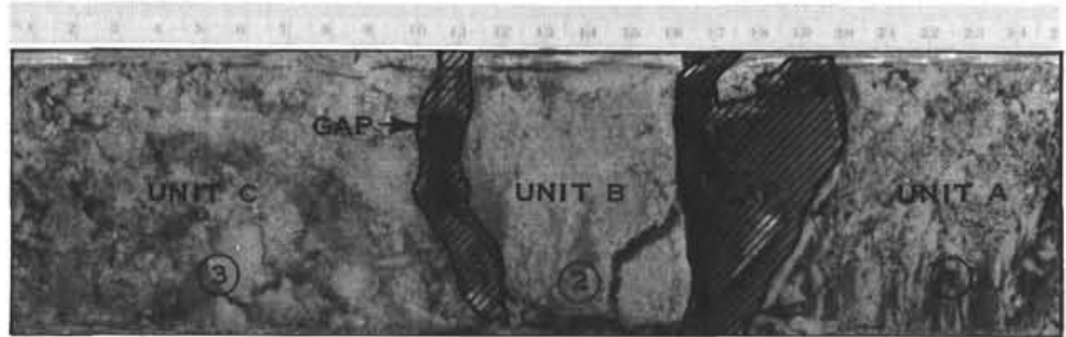

Figure 5. Site 299, Core 36, Section 1. Unit A - olive-gray (5Y 3/2) to darkgreenish-gray (5GY 4/1), irregularly thin bedded and horizontally fractured, noncalcareous, very slightly pyritic clay, sample contains a very slight trace of muscovite mica; trace of silt-size, brassy pyrite: essentially $100 \%$ clay fraction. No nannoplankton, foraminifera, or siliceous microfossils were observed. Unit B - olive-gray $(5 Y 4 / 1)$, soft, nonbedded, massive, noncalcareous, clayey siltstone. Sample consists of $2 \%$ medium, $5 \%$ fine, and $5 \%$ very fine sand; $40 \%$ quartzose silt fractions; $5 \%$ fine-sand to silt-size muscovite mica; $5 \%$ black fine-sand to silt-size biotite mica; $10 \%$ pale-green, medium-sand to silt-size glauconite; and 28\% clay-size fractions. Noncalcareous, no fossils noted. Contacts with overlying and underlying units are not complete, although they appear to be in sharp contact. This silty unit is not gradationally bedded. Sand grains are milky to clear, very angular to subangular. Unit is very poorly sorted and immature, and is probably the result of turbidity sedimentation. Unit $C$ olive-gray (5Y 3/2), soft, firm nonbedded, noncalcareous clay. This unit contains a trace of silt-size brassy pyrite; trace of silt-size fresh muscovite mica: essentially $100 \%$ clay-size fraction. No nannoplankton, foraminifera, or siliceous microfossils were observed. Unit contains common to abundant, medium-sand-size ovate objects which strongly resemble fecal pellets. Pellets have the same color and lithology as the enclosing clay.

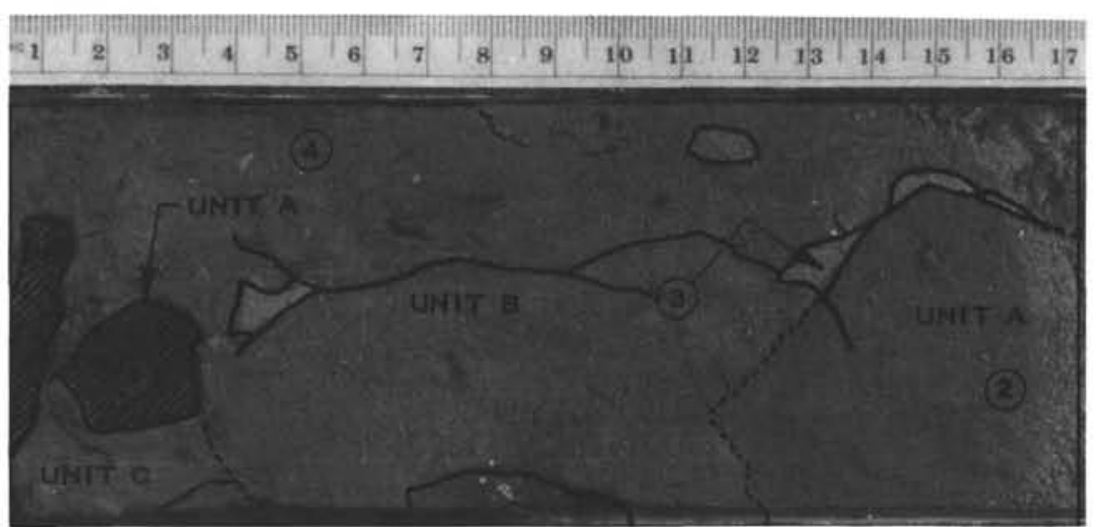

Figure 6. Site 302, Core 3, Section 0 (top). Unit A - dark-greenish-gray $(5 G 4 / 1)$, very soft, nonlaminated, diatom- and silicoflagellate-rich clay. Unit contains very rare calcareous nannoplankton, and very abundant siliceous microfossils. No foraminifera were noted. Unit contains about $60 \%$ clay and $40 \%$ fossil (mostly siliceous types) debris. Unit B - greenish-gray (5G 6/1); lithology as Unit A. Contains rare to common isolated masses of finely divided brassy pyrite. Contains thin (1- to 2-mm thick), discontinuous, randomly oriented seams of material which appear to be identical to Unit A. Unit is very slightly calcareous, containing common calcareous nannoplankton. Unit $C$ - moderate-olive-brown (5Y 3/4), very soft, plastic, nonlaminated, diatom- and silicoflagellate-rich clay. Unit contains common to abundant calcareous nannoplankton, about $40 \%$ siliceous microfossil debris, and $60 \%$ clay. Unit is very slightly calcareous. Contains rare to common planktonic foraminifera and common to abundant spore and pollen remains. Both Units $A$ and $C$ appear to be displaced erratic blocks, their presence due perhaps to plastic flow into Unit B (the dominant lithology). Contacts with both Units $A$ and $C$ are sharp and irregular in outline. 


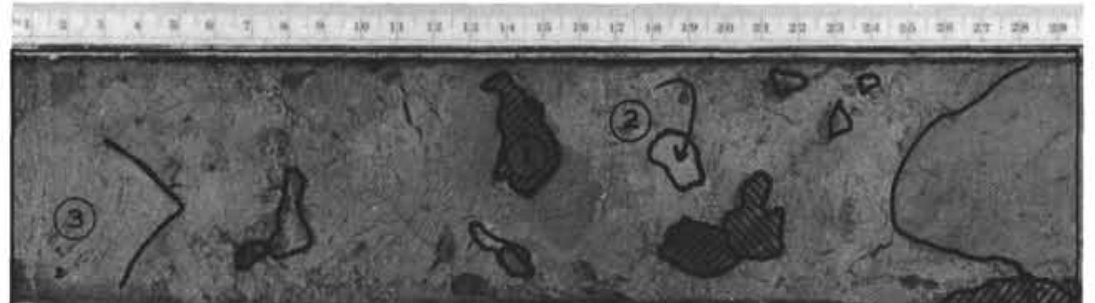

Figure 7. Site 302, Core 3, Section 0 (bottom). Greenish-gray (5G 6/1), very soft, plastic, nonlaminated, diatom- and silicoflagellate-rich clay. Unit contains very abundant siliceous microfossils and rare calcareous nannoplankton. No foraminifera observed in the greenish clay. Lithology consists of about $40 \%$ siliceous microfossils and $60 \%$ clay (zeolitic?). Within this core are pea-size to large-marble-size pieces of moderate-olive-brown (5Y 3/4), soft, plastic, diatom- and silicoflagellate-rich clay. These small blocks are distincly darker in color and contain abundant spore and pollen grains and common calcareous nannoplankton and planktonic foraminifera. These blocks appear to be due to plastic flow and introduction into the dominant greenish-gray lithology.

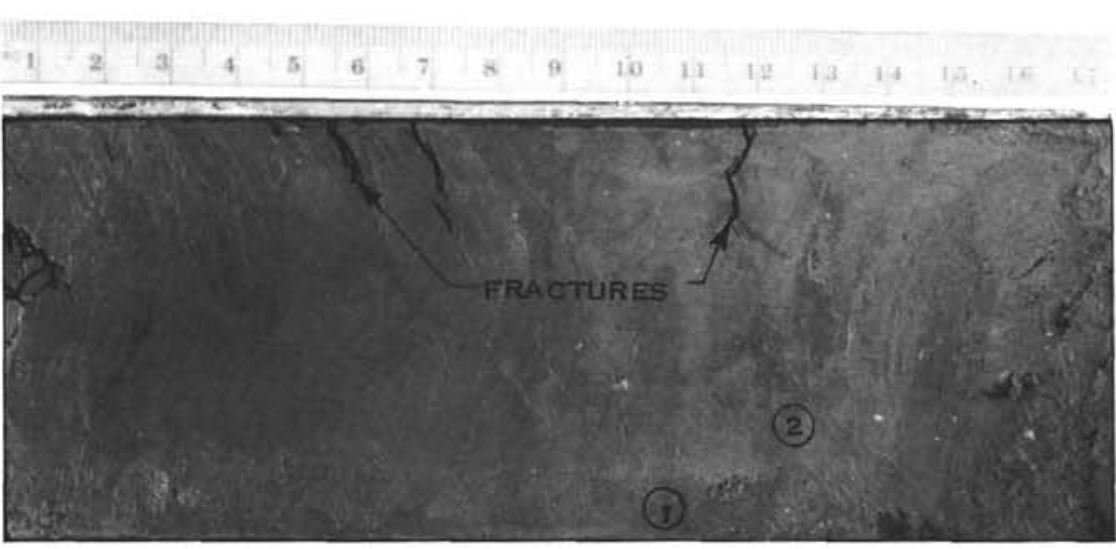

Figure 8. Site 302, Core 7, Section 0 (top). Olive-gray (5Y 3/2), very soft and plastic, firm, nonlaminated, clayey diatom and silicoflagellate ooze. This sample is completely noncalcareous; no foraminifera or calcareous nannoplankton were observed. Sample consists of about $80 \%$ siliceous microfossils and about 20\% clay-size fraction; probably a zeolitic clay. Sample is uniform throughout its length; no bedding contacts were noted. Absence of any trace of calcareous microfossils indicates sediment was deposited below the carbonate compensation depth.

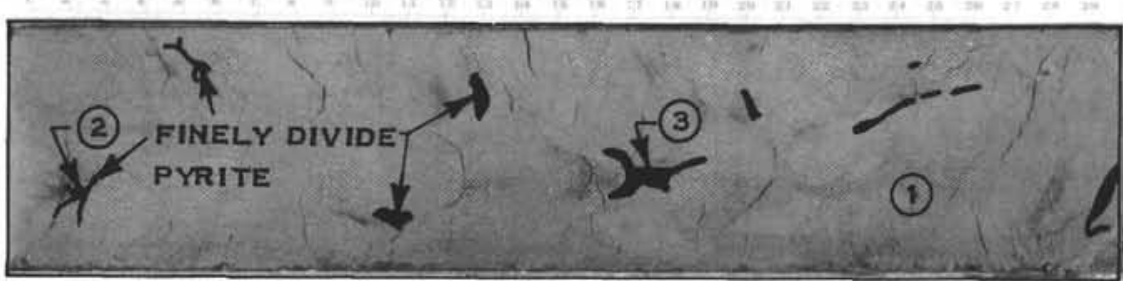

Figure 9. Site 302, Core 7, Section 0 (bottom). Grayish-olive (10Y 4/2), soft, plastic, firm, nonbedded, noncalcareous, slightly pyritic, diatom- and silicoflagellate-rich clay. Grayish-olive clay is uniform throughout length of core, although there are very irregular, randomly oriented and discontinuous patches of black material which are finely divided pyrite. Sample is entirely noncalcareous. Fossils are all siliceous types, including diatoms, silicoflagellates, rare radiolarians and abundant sponge spicules. No calcareous foraminifera observed. Indicative of cold waters below the carbonate compensation depth.

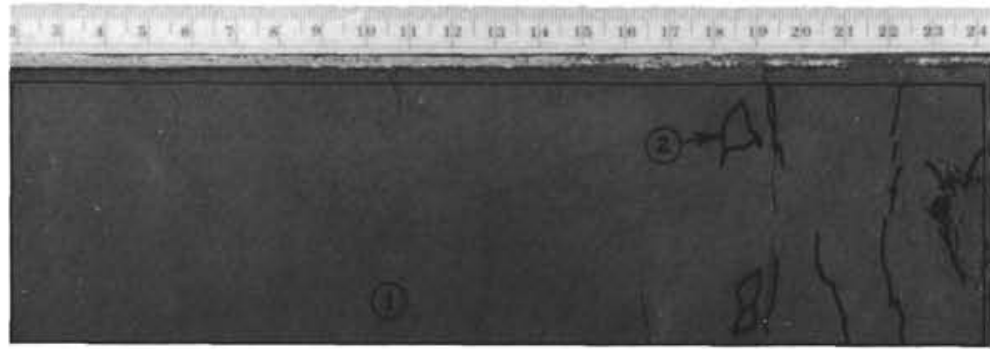

Figure 10. Site 302, Core 8, Section 0 (top). Olive-gray (5Y 4/1), very soft, plastic, firm massive and uniform, nonlaminated, noncalcareous, diatom and silicoflagellate ooze. Sample is completely noncalcareous and no calcareous foraminifera or calcareous nannoplankton were observed. Sample consists entirely of siliceous Radiolaria, diatoms, and silicoflagellates, with $1 \%-2 \%$ detrital clay fraction. Core surface shows some minor black staining due to pyrite. The sediment comprising this core was deposited below the carbonate compensation depth. 


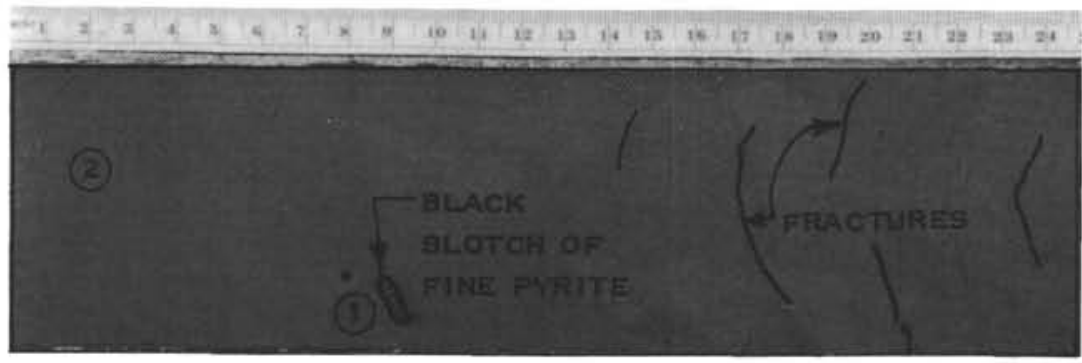

Figure 11. Site 302, Core 8, Section 0 (bottom). Olive-gray (5Y 4/1), uniform, soft firm, nonbedded, very slightly clayey diatom and silicoflagellate ooze. This sample is very uniform in both lithology and color, and contains essentially $100 \%$ siliceous microfossils, including radiolarians, diatoms silicoflagellates. Contains a slight trace of detrital quartzose silt and a trace of clay. Surface of sample contains a few irregularly shaped pockets of black to very-dark-gray pyritic siliceous ooze, 3-10 $\mathrm{mm}$ in diameter. Sample is entirely noncalcareous and no calcareous microfossils were noted.

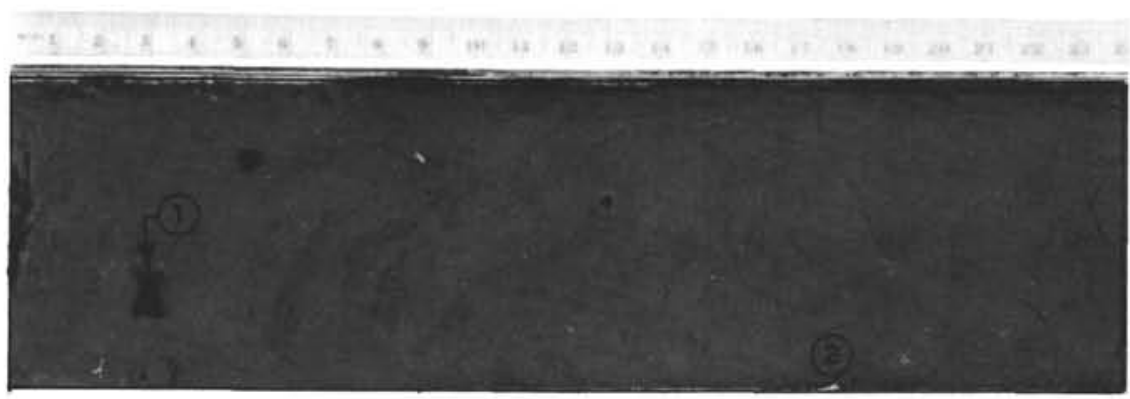

Figure 12. Leg 31 Site 302, Core 10, Section 0. Olive-gray (5Y 3/2) to dark greenish-gray (5GY 4/1), very soft, plastic, firm, massive and uniform, nonlaminated, noncalcareous, diatom and silicoflagellate ooze, sample is irregularly mottled and "pseudolaminated" due to the presence of abundant, very finely divided pyrite. Mottling could be due to bioturbation of the sediment by burrowing organisms. No foraminifera or calcareous nannoplankton noted. Sample consists of siliceous microfossils plus one to two percent clay mineral fraction.

TABLE 3

Carbonate Content and Concentrations of Organic Fractions in Geochemical Samples from DSDP Leg 31

\begin{tabular}{|c|c|c|c|c|c|c|c|c|}
\hline \multirow[b]{2}{*}{ Section } & \multirow[b]{2}{*}{ Geologic $\mathrm{Age}^{\mathrm{a}}$} & \multirow[b]{2}{*}{$\begin{array}{l}\text { Subbottom } \\
\text { Depth (m) }\end{array}$} & \multicolumn{2}{|c|}{ Carbonates } & \multicolumn{3}{|c|}{ Organic Carbon } & \multirow[b]{2}{*}{$\begin{array}{l}\text { Total } \\
\text { Lipid }\end{array}$} \\
\hline & & & $\begin{array}{l}\text { Carbon } \\
\text { (wt. \%) }\end{array}$ & $\begin{array}{l}\text { Calcium } \\
\text { (wt. \%) }\end{array}$ & $\begin{array}{c}\text { Total } \\
\text { (wt. \%) }\end{array}$ & $\begin{array}{l}\text { Lipid } \\
\text { (wt. \%) }\end{array}$ & $\begin{array}{c}\text { Kerogen } \\
\text { (wt. \%) }\end{array}$ & \\
\hline $299-7-3$ & Early Pleistocene & $156.25-156.55$ & 0.15 & 1.25 & 0.07 & 0.004 & 0.07 & 0.057 \\
\hline $299-22-1$ & Early Pleistocene & $200.75-201.00$ & 0.18 & 1.50 & 0.95 & 0.05 & 0.90 & 0.053 \\
\hline $299-30-3$ & Pliocene & $327.25-327.50$ & 0.49 & 4.08 & 0.51 & 0.02 & 0.49 & 0.039 \\
\hline $299-36-1$ & Late Miocene & $495.25-495.50$ & 0.62 & 5.17 & 0.67 & 0.03 & 0.64 & 0.045 \\
\hline $302-3-0$ (top) & Pleistocene & $39.0-39.25$ & 0.43 & 3.58 & 0.56 & 0.03 & 0.53 & 0.054 \\
\hline 302-3-0 (bottom) & Pleistocene & $39.25-39.50$ & 0.22 & 1.83 & 0.45 & 0.02 & 0.43 & 0.044 \\
\hline $302-7-0$ (top) & Early Pliocene & $115.00-115.25$ & 0.15 & 1.25 & 0.65 & 0.03 & 0.62 & 0.046 \\
\hline $302-7-0$ (bottom) & Early Pliocene & $115.25-115.50$ & 0.42 & 3.50 & 0.72 & 0.02 & 0.70 & 0.028 \\
\hline $302-8-0$ (top) & Late Miocene & $134.00-134.25$ & 0.10 & 0.83 & 0.61 & 0.02 & 0.59 & 0.033 \\
\hline $302-8-0$ (bottom) & Late Miocene & $134.25-134.50$ & 0.08 & 0.67 & 0.70 & 0.02 & 0.68 & 0.029 \\
\hline $302-10-0$ (top) & Late Miocene & $171.00-171.25$ & 0.26 & 2.17 & 0.95 & 0.03 & 0.92 & 0.032 \\
\hline
\end{tabular}

${ }^{\text {a }}$ Source is DSDP Summary Report. 
TABLE 3

Carbon Isotopic Composition of Lipid and Kerogen Fractions in Geochemical Samples from DSDP Leg 31

\begin{tabular}{llcc}
\hline & \multicolumn{3}{c}{ Carbon Isotopic Composition, } \\
& \multicolumn{3}{c}{$\delta C_{\text {PDB }}^{13}$} \\
\cline { 2 - 4 } \multicolumn{1}{c}{ Section } & Lipid & Kerogen & Difference \\
& & L-K \\
\hline $299-17-3$ & $-25.2^{\mathrm{a}}$ & -25.1 & -0.1 \\
$299-22-1$ & -25.7 & -22.8 & -2.9 \\
$299-30-3$ & -25.6 & -23.9 & -1.7 \\
$299-36-1$ & -26.5 & -23.3 & -3.2 \\
$302-3-0$ (top) & -26.2 & -25.7 & -0.5 \\
$302-3-0$ (bottom) & -25.7 & -22.6 & -3.1 \\
$302-7-0$ (top) & -25.3 & -21.9 & -3.4 \\
$302-7-0$ (bottom) & -24.4 & -21.8 & -2.6 \\
$302-8-0$ (top) & -24.6 & -22.6 & -2.0 \\
$302-8-0$ (bottom) & -25.2 & -21.6 & -3.6 \\
$302-10-0$ (top) & -24.9 & -21.8 & -3.1 \\
\hline
\end{tabular}

increasing depth in each hole, respectively, rather than for the two holes together. The percent concentrations of calcium carbonate are calculated from the carbonate carbon values.

The sections from Site 299 are poorly sorted and contain silt-sized grains in all cases. In Section 299-36-1 there is evidence of turbidity flow. Carbonate, primarily as calcium carbonate, increases progressively with depth. Siliceous microfossils are present in all intervals. Calcareous microfossils are present in Section 299-77-3, but are absent deeper in the hole. This suggests an increase in water depth to below the carbonate compensation zone and consequent recrystallization. The much lower concentration of organic matter in Section 299-77. 3 relative to that found deeper in the hole also suggests a different environment at the time of deposition.

The sections from Site 302 are composed almost entirely of clay-sized minerals. Carbonate, primarily as calcium carbonate, is present throughout the depth interval sampled. There is, however, no trend with depth as at Site 299. In Section 302-3-0 there is evidence of plastic flow. Spores and pollen grains are present suggesting a terrestrial contribution to the sediment. Calcareous microfossils are present, but disappear deeper in the hole. At Site 299, this observation is interpreted as increase in water depth to below the carbonate compensation zone and consequent recrystallization. The concentration of organic matter is relatively uniform throughout the series of samples from this hole.

In sediments protected from molecular oxygen the ratio of lipids to total organic matter would be expected to increase with age and depth of burial as the reactions which lead to genesis of petroleum progress. At Sites 299 and 302 this trend is not observed, suggesting either that (1) the combination of time and temperature are insufficient to bring about significant petroleum genesis, (2) the products of genesis are flushed out of the compacting rock, an unlikely event, or (3) the organic fraction is not of such nature as to generate liquid oil (Erdman, in press).

The carbon isotopic values of the lipid fractions cluster closely, varying by only $1.26 \%$ at Site 299 and by $1.62 \%$ at Site 302 . For both sites the variation is $2.06 \%$. The absolute values suggest that the organic fraction of these sediments derived from organisms which inhabited typically open-marine environments (Scalan and Morgan, 1970; Gearing and Parker, 1973).

As organic diagenesis proceeds, particularly under anaerobic conditions, the spread between the values of the carbon isotopic composition of the lipid and kerogen fractions would be expected to increase, with the values for the lipid fraction being the more negative and becoming more so with increasing depth and age. This trend was observed in both holes (Scalan and Morgan, 1970; Degens, 1969).

\section{REFERENCES}

Degens, E. T., 1969. Biogeochemistry of stable carbon isotopes. In Eglinton, G. and Murphy, M. T. J., Sr. (Eds.), Organic Geochemistry, methods and results: New York (Springer Verlag), p. 304-329.

Erdman, J. G., in press. Geochemical formation of oil. In Petroleum and global tectonics: Princeton Univ. Conf. No. 109, Princeton Univ., March 10, 11, 1972. (Also presented at Internatl. Geol. Congr. 24, Sec. V, Mineral Fuels, Montreal, Canada, August 20-30, 1972.)

Erdman, J. G., Schorno, K. S., and Scalan, R. S., 1974. Geochemistry of carbon: Deep Sea Drilling Project, Legs 22, 24, 26, 27, and 28. In Fisher, R. L., Bunce, E. T., et al., Initial Reports of the Deep Sea Drilling Project, Volume 24: Washington (U.S. Government Printing Office), p. 11691176.

, in press. Geochemistry of carbon and sulfur: Deep Sea Drilling Project Leg 29. In Kennett, J. P., Houtz, R. E., et al., Initial Reports of the Deep Sea Drilling Project, Volume 29: Washington (U.S. Government Printing Office).

Gearing, P. J. and Parker, P. L., 1973. Stable carbon isotope ratios of organic matter from continental margins: Paper presented, Geochem. Soc., 17th Ann. Meet., Dallas, Texas, November 13, 1973.

Scalan, R. S. and Morgan, T. D., 1970. Isotope ratio mass spectrometer instrumentation and application to organic matter contained in Recent sediments, Internatl. J. Mass Spectrom. Ion Phys. v. 4, p. 267-281. 